\title{
Oxidation of Carbon Monoxide and Methane by Pseudomonas methanica
}

\author{
By T. FERENCI, T. STRØM* AND J. R. QUAYLE \\ Department of Microbiology, University of Sheffield, \\ Sheffield, SIо $2 T N, U . K$.
}

(Received 2I March I975; revised 30 May 1975)

\begin{abstract}
SUMMAR Y
The oxidation of carbon monoxide and methane by suspensions and ultrasonic extracts of Pseudomonas methanica was studied. A continuous assay for the oxidation of $\mathrm{CO}$ to $\mathrm{CO}_{2}$ was devised, using $\mathrm{O}_{2}$ and $\mathrm{CO}_{2}$ electrodes in combination. Stoicheiometries of $\mathrm{CO}$-dependent $\mathrm{CO}_{2}$ formation, $\mathrm{O}_{2}$ consumption and NADH oxidation, and the partial stoicheiometries of methane-dependent NADH oxidation, suggest the involvement of a mono-oxygenase in these oxidations. Evidence is presented suggesting methane and $\mathrm{CO}$ oxidation are catalysed by a single enzyme system, distinct, at least in part, from the NADH oxidase present in extracts. Ethanol was able to provide the reductant necessary for $\mathrm{CO}$ oxidation by cell suspensions, though the metabolism of ethanol by $P$. methanica was found unlikely to result in substrate-level formation of NADH; the means whereby alcohol oxidation could supply reductant for the mono-oxygenase are discussed.
\end{abstract}

\section{INTRODUCTION}

Ribbons \& Michalover (1970) briefly reported a methane-stimulated NADH oxidase in cell-free extracts of Methylococcus capsulatus. Although many speculative reviews deal with this topic (Foster, 1962; Whittenbury, 1969; Ribbons, Harrison \& Wadzinski, I970; Wilkinson, I97I; Quayle, I972; Van Dijken \& Harder, 1975), no other study of methane oxidation by cell-free extracts has been published. This may be because of the apparent inability to obtain cell-free extracts which reproducibly show methane-oxidizing activity (e.g. Quayle, 1972). This paper describes some properties of a methane-dependent NADH oxidase system in extracts of methane-grown Pseudomonas methanica, prepared as previously described (Ferenci, 1974). The term NADH oxidase does not necessarily refer to a single, defined activity but to any activity, under the conditions specified, resulting in oxidation of NADH with oxygen as the terminal electron acceptor.

Washed suspensions of methane-utilizing bacteria catalyse the slow oxidation of carbon monoxide (CO) to $\mathrm{CO}_{2}$ (Hubley, Mitton \& Wilkinson, I974), and $\mathrm{CO}$ stimulates the consumption of oxygen by these organisms (Hubley et al. 1974; Ferenci, 1974). This paper confirms the suggestions of Ferenci (1974) that the oxidation of $\mathrm{CO}$ in P. methanica is catalysed by an NADH-requiring mono-oxygenase. The relationship between the enzymes of $\mathrm{CO}$ oxidation and those of methane oxidation, and possible sources of reductant for these oxidations, are considered.

* Present address: Institute of Fishery Technology Research, Box I159, Tromsø, Norway. 


\section{METHODS}

Materials. Carbon monoxide and methane (research grade) were obtained from The British Oxygen Co., Special Gases, London, ethane ( $99 \%$ ) from BDH, and methane (approximately $95 \%$, used for the growth of organisms only) from the Greater London Council, Department of Public Health Engineering, Isleworth, Middlesex. Gases were added to all assays as saturated solutions in water at $25^{\circ} \mathrm{C}$ and atmospheric pressure; the concentrations of gases in solution were taken from solubility tables (Seidell, 1920). Coenzymes and isocitrate dehydrogenase were from Boehringer Corp., London, and carbonic anhydrase was from Sigma.

Growth of the organism and preparation of extracts. Pseudomonas methanica was grown and harvested as previously specified (Ferenci, 1974). Suspensions were washed once in buffer containing $20 \mathrm{mM}$-potassium phosphate- $5 \mathrm{mM}-\mathrm{MgCl}_{2}, \mathrm{pH} 7 \cdot 0$, before preparation of extracts and the particulate fraction of extracts as previously described (Ferenci, 1974).

Simultaneous measurement of $\mathrm{CO}_{2}$ formation and $\mathrm{O}_{2}$ uptake. A water-jacketed Rank oxygen electrode chamber (Rank Bros., Bottisham, Cambridge), in which the $\mathrm{O}_{2}$ electrode is housed at the base, was used as the reaction vessel. The $\mathrm{CO}_{2}$ electrode was incorporated into the lid of the vessel; the lid consisted of a disc of stiff plastic (of a diameter to give a tight fit into the reaction chamber) through which a small hole had been drilled for the addition of reagents and removal of air bubbles. The $\mathrm{CO}_{2}$ electrode (Radiometer type E5036, Radiometer A/S, Copenhagen) was coupled to a Radiometer PHM 7I mark II pH meter with a PHA 935 $p \mathrm{CO}_{2}$ module. The signal from the $\mathrm{pH}$ meter was displayed on a Rikadenki B 24I twochannel recorder (TEM Sales Ltd., Crawley, Sussex); the second channel was used via the $\mathrm{O}_{2}$ electrode to monitor $\mathrm{O}_{2}$ disappearance from the reaction chamber. The signal from the $\mathrm{pH}$ meter was offset by ${ }_{150} \mathrm{mV}$, which was registered at zero $\mathrm{CO}_{2}$ concentration, to enable the signal to be displayed on the recorder. References to $\mathrm{CO}_{2}$ throughout are to the total $\mathrm{CO}_{2}$ in solution, including the hydrated forms of $\mathrm{CO}_{2}$.

The $\mathrm{CO}_{2}$ electrode was used essentially as described by Nicholls, Shepherd \& Garland (I967). It was calibrated with $\mathrm{CO}_{2}$ generated from isocitrate in the presence of isocitrate dehydrogenase; $\mathrm{NaHCO}_{3}$ solutions were used as secondary standards (Nicholls et al. 1967). A silicone rubber membrane (Radiometer type D606) was used with the $\mathrm{CO}_{2}$ electrode and the $\mathrm{pH}$ electrode compartment contained $50 \mathrm{mM}-\mathrm{NaCl}_{2}, \mathrm{I} \mathrm{mm}-\mathrm{NaHCO}_{3}$ and $100 \mu \mathrm{g}$ carbonic anhydrase $/ \mathrm{ml}$. The time for a $90 \%$ response to the addition of $50 \mu \mathrm{M}-\mathrm{NaHCO}_{3}$ to the reaction chamber of the electrode containing $50 \mathrm{~mm}$-sodium-potassium phosphate buffer $\mathrm{pH} 7 \cdot 0$, and I00 $\mu \mathrm{g}$ carbonic anhydrase $/ \mathrm{ml}$, was variable from membrane to membrane but was usually under $30 \mathrm{~s}$. The sensitivity and stability of the $\mathrm{CO}_{2}$ electrode was such that it could be routinely used with a full-scale deflection on the recorder equivalent to less than $20 \mu \mathrm{M}-\mathrm{CO}_{2}$. The suitability of the $\mathrm{CO}_{2}$ electrodc for measuring enzyme-dependent rates of $\mathrm{CO}_{2}$ formation was shown by the linear dependence of the rate of $\mathrm{CO}_{2}$ formation, as measured by the slope of the recorder tracing, on the concentration of isocitrate dehydrogenase in the presence of isocitrate in the assay described below. The specific activity of isocitrate dehydrogenase, as calculated from $\mathrm{CO}_{2}$ output, was $0.793 \mu \mathrm{mol} \mathrm{CO}$ formed $/ \mathrm{min} / \mathrm{mg}$ protein; this agreed with that of the same enzyme preparation assayed spectrophotometrically under identical conditions, namely $0 \cdot 778 \mu \mathrm{mol} \mathrm{NADPH}$ formed $/ \mathrm{min} / \mathrm{mg}$ protein.

Oxidations of substrates by cell suspensions were assayed as previously described (Ferenci, 1974).

Carbon monoxide mono-oxygenase and methane mono-oxygenase activities. Each assay mixture is described in the legend to the relevant Figure; all assays were performed at $25^{\circ} \mathrm{C}$. 
The mono-oxygenase activities were also followed spectrophotometrically at $25^{\circ} \mathrm{C}$, by measurement of CO- or methane-dependent rates of NADH oxidation as previously described (Ferenci, 1974). Specific activities of enzyme preparations are expressed in terms of the $\mathrm{CO}$ - or methane-dependent rates of $\mathrm{NADH}$ oxidation $/ \mathrm{min} / \mathrm{mg}$ protein, i.e. corrected for substrate-independent NADH oxidation.

Inhibition of carbon monoxide mono-oxygenase activity. Assays were performed in the $\mathrm{CO}_{2}$ electrode; the assay mixture, in a total volume of $2 \mathrm{ml}$ at $25^{\circ} \mathrm{C}$, consisted of $50 \mathrm{~mm}$ sodium-potassium phosphate buffer $\mathrm{pH} 7 \cdot 0$, I00 $\mu \mathrm{g}$ carbonic anhydrase $/ \mathrm{ml}, 0 \cdot 2 \mathrm{mM}-\mathrm{NADH}$ and $0.1 \mathrm{ml}$ of particulate membrane fraction plus inhibitors. The specific activity of the particulate membrane fraction was $23.6 \mathrm{nmol} \mathrm{CO}_{2}$ formed $/ \mathrm{min} / \mathrm{mg}$ protein. The reaction was initiated by adding $\mathrm{CO}$ to a concentration of $24 \mu \mathrm{M}$.

Alcohol and aldehyde oxidase and dehydrogenase activities were assayed in the Rank $\mathrm{O}_{2}$ electrode at $25{ }^{\circ} \mathrm{C}$ with a reaction volume of $2 \mathrm{ml}$. The assay mixtures contained $50 \mathrm{~mm}$ sodium phosphate buffer $\mathrm{pH} 8.0$, cell-free extract containing 0.5 to $\mathrm{I} \cdot 0 \mathrm{mg}$ protein and either methanol, ethanol, formaldehyde or acetaldehyde (I mM). To demonstrate the dehydrogenase activities, IomM- $\mathrm{NH}_{4} \mathrm{Cl}$ plus I mM-phenazine methosulphate (PMS) were also added to the assay mixture in the $\mathrm{O}_{2}$ electrode. The glutathione-dependent, NAD-linked formaldehyde dehydrogenase was assayed as described by Johnson \& Quayle (1964).

Formate dehydrogenase. This enzyme was assayed spectrophotometrically, at $340 \mathrm{~nm}$ and $25^{\circ} \mathrm{C}$ in a $\mathrm{I} \mathrm{ml}$ reaction mixture containing $50 \mathrm{~mm}$-sodium-potassium phosphate buffer $\mathrm{pH} 7.0,0.2 \mathrm{mM}-\mathrm{NAD}, 2.5 \mathrm{~mm}$-sodium formate and cell-free extract containing up to $80 \mu \mathrm{g}$ protein. The order of addition of reagents suggested by Johnson \& Quayle (I964) was followed.

Isocitrate dehydrogenase. The assay mixture in the $\mathrm{CO}_{2}$ electrode, total volume $2 \mathrm{ml}$ at $25^{\circ} \mathrm{C}$, contained : $50 \mathrm{~mm}$-sodium-potassium phosphate buffer $\mathrm{pH} 7 \cdot 0,2 \mathrm{mM}-\mathrm{MgCl}_{2}, 0.8 \mathrm{mM}$ NADP, $0.5 \mathrm{~mm}$-isocitrate and $200 \mu \mathrm{g}$ carbonic anhydrase. The reaction was started by adding known amounts of isocitrate dehydrogenase.

Protein was estimated by the method of Lowry et al. (I95I).

\section{RESULTS}

The carbon monoxide mono-oxygenase activity

In the presence of a particulate membrane preparation, simultaneous stimulations of NADH oxidation and $\mathrm{O}_{2}$ uptake were accompanied by the oxidation of $\mathrm{CO}$ to $\mathrm{CO}_{2}$ (Fig. I). Carbon monoxide alone (Fig. I $a$ ) or NADH alone (Fig. I $b$ ) gave little stimulation of $\mathrm{CO}_{2}$ formation but the latter stimulated $\mathrm{O}_{2}$ uptake. If the rates of $\mathrm{CO}_{2}$ formation and $\mathrm{O}_{2}$ uptake observed without $\mathrm{CO}$ (Fig. $\mathrm{I} b$ ) were maintained during $\mathrm{CO}$-dependent respiration, and are corrected for, the addition of $93 \mathrm{nmol} \mathrm{CO}$ resulted in the formation of I IO $\mathrm{nmol} \mathrm{CO}$ and the consumption of IOI nmol $\mathrm{O}_{2}$. The equivalence of $\mathrm{CO}$ added, $\mathrm{CO}_{2}$ formed, $\mathrm{O}_{2}$ consumed and NADH oxidized, confirmed by further experiments (Table I), is consistent with the following reaction for $\mathrm{CO}$ oxidation:

$$
\mathrm{CO}+\mathrm{O}_{2}+\mathrm{NADH}+\mathrm{H}^{+} \rightarrow \mathrm{CO}_{2}+\mathrm{NAD}^{+}+\mathrm{H}_{2} \mathrm{O} .
$$

If the rate of $\mathrm{CO}$-independent respiration was not (as assumed) maintained during $\mathrm{CO}$ oxidation, the amounts of $\mathrm{O}_{2}$ and NADH consumed would be even higher, making less. likely the alternative mechanism:

$$
2 \mathrm{CO}+\mathrm{O}_{2} \rightarrow 2 \mathrm{CO}_{2}
$$




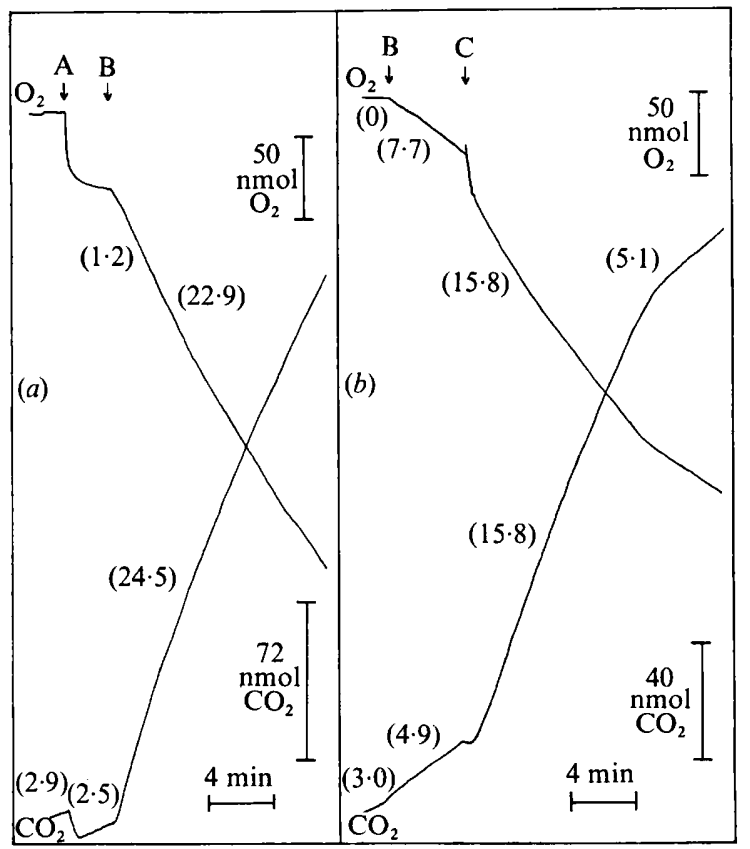

Fig. I. Carbon monoxide oxidation by a particulate fraction of cell-free extracts. The assay mixtures in a final volume of $2 \mathrm{ml}$ in the dual $\mathrm{CO}_{2}-\mathrm{O}_{2}$ electrode vessel, contained $50 \mathrm{mM}$-sodium-potassium phosphate buffer $\mathrm{pH} 7.0$ and $200 \mu \mathrm{g}$ carbonic anhydrase, together with: (a) $0.75 \mathrm{mg}$ protein, obtained by centrifuging a cell-free extract (Ferenci, 1974) for $60 \mathrm{~min}$ at $38000 \mathrm{~g}$ and resuspending the pellet formed in $20 \mathrm{mM}$-sodium-potassium phosphate buffer $\mathrm{pH} 7.0$ containing $5 \mathrm{mM}-\mathrm{MgCl}_{2}$; (b) $0.6 \mathrm{mg}$ protein, prepared as for $(a)$. The additions, at the points arrowed, were: A, $0.186 \mu \mathrm{mol}$ $\mathrm{CO} ; \mathrm{B}, 0.4 \mu \mathrm{mol} \mathrm{NADH} ; \mathrm{C}, 0.093 \mu \mathrm{mol} \mathrm{CO}$. The figures in parentheses give the rates of $\mathrm{O}_{2}$ consumption or $\mathrm{CO}_{2}$ formation, in $\mathrm{nmol} / \mathrm{min}$.

\section{Table I. Stoicheiometries of NADH-dependent oxidations of methane and carbon monoxide by cell-free extracts}

$\mathrm{CO}_{2}$ formation and oxygen uptake were measured simultaneously as described in Methods. The assay mixture $(2.4 \mathrm{ml})$ contained $50 \mathrm{~mm}$-sodium-potassium phosphate buffer $\mathrm{pH} 7.0,0.28 \mathrm{~mm}$ NADH and $50 \mu \mathrm{g}$ carbonic anhydrase $/ \mathrm{ml}$; the gaseous substrates were added as known amounts of saturated solutions in water at $25^{\circ} \mathrm{C}$. With $\mathrm{CO}$ as substrate, the $38000 \mathrm{~g}$ pellet fraction was used to catalyse the reaction, with $0.26 \mathrm{mg}$ protein $/ \mathrm{ml}$ in the assay. With methane as substrate, cell-free extract was used, at $0.68 \mathrm{mg}$ protein $/ \mathrm{ml}$. NADH oxidation was followed separately, spectrophotometrically, as described in Methods. The concentrations of the reactants, in a volume of $\mathrm{I} \cdot 2 \mathrm{ml}$, were identical to those above except that carbonic anhydrase was omitted. The values quoted have been corrected for substrate-independent $\mathrm{CO}_{2}$ formation, $\mathrm{O}_{2}$ uptake and NADH oxidation. All results are given in $\mu \mathrm{mol} / \mathrm{ml}$ assay mixture.

$\begin{array}{lccc}\text { Substrate added } & \mathrm{CO}_{2} \text { produced } & \mathrm{O}_{2} \text { removed } & \begin{array}{r}\mathrm{NADH} \\ \text { oxidized }\end{array} \\ \begin{array}{l}\text { Carbon monoxide } \\ \text { I5.5 }\end{array} & 17 \cdot 4 & 13 \cdot 8 & \\ 31 \cdot 0 & 32 \cdot 4 & 34 \cdot 3 & 36 \cdot 3 \\ \begin{array}{l}\text { Methane } \\ 21 \cdot 3\end{array} & - & & 36 \cdot 5 \\ 42 \cdot 0 & - & 37 \cdot 4 & 21 \cdot 1 \\ 4 & - & 36 \cdot 2 & 39 \cdot 0\end{array}$



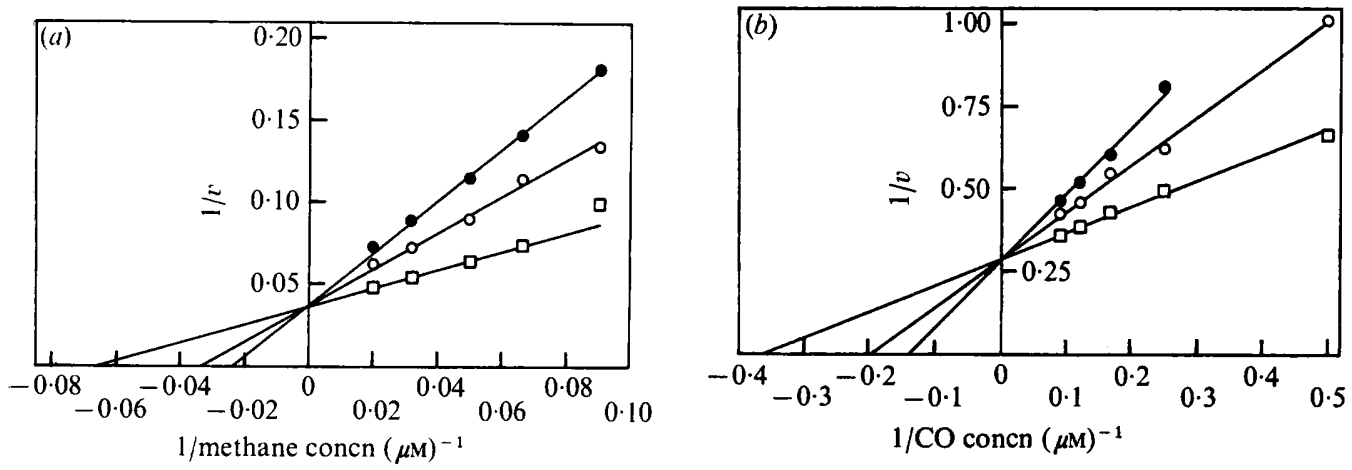

Fig. 2. Effect of ammonium chloride on the kinetics of methane and CO oxidation by cell suspensions. (a) The reaction mixture in the oxygen electrode vessel (total volume $2 \mathrm{ml}$ ) contained $50 \mathrm{~mm}$ sodium-potassium phosphate $\mathrm{pH} 7 \cdot 0,0.25 \mathrm{mg}$ dry wt $P$. methanica, and methane at the concentrations shown. $\square$, No further additions; $O$, with $10 \mathrm{~mm}-\mathrm{NH}_{4} \mathrm{Cl}$; 0 , with $20 \mathrm{~mm}-\mathrm{NH}_{4} \mathrm{Cl}$. Rates of oxygen uptake, $v$, are expressed as $\mathrm{nmol}_{2}$ consumed $/ \mathrm{min}$. (b) The reaction mixture in the dual $\mathrm{CO}_{2}-\mathrm{O}_{2}$ electrode vessel (total volume $2 \mathrm{ml}$ ) contained $50 \mathrm{~mm}$-sodium-potassium phosphate $\mathrm{pH} 7 \cdot 0$, $200 \mu \mathrm{g}$ carbonic anhydrase, I mM-ethanol, $0.0475 \mathrm{mg}$ dry wt $P$. methanica, $\mathrm{CO}$ at the concentrations

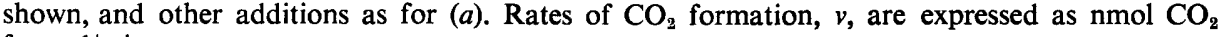
formed/min.

\section{The methane mono-oxygenase activity}

Cell-free extracts of $P$. methanica exhibited, in addition, a methane-dependent NADH oxidase activity (Ferenci, I974) similar to that described for $M$. capsulatus (Ribbons \& Michalover, 1970). The partial stoicheiometry of methane-dependent NADH oxidation and $\mathrm{O}_{2}$ consumption, assuming endogenous rates continued unchanged during methane oxidation (Table I), is consistent with methane oxygenation being catalysed by a mono-oxygenase:

$$
\mathrm{CH}_{4}+\mathrm{O}_{2}+\mathrm{NADH}+\mathrm{H}^{+} \rightarrow\left[\mathrm{CH}_{3} \mathrm{OH}\right]+\mathrm{NAD}^{+}+\mathrm{H}_{2} \mathrm{O} \text {. }
$$

The stoicheiometry indicates that methanol is the product; this was not directly demonstrated. If the rate of methane-independent $\mathrm{NADH}$ oxidation and $\mathrm{O}_{2}$ uptake was not (as assumed) constant during methane-dependent NADH oxidation, more $\mathrm{O}_{2}$ and NADH would be consumed for each amount of methane added thus making less likely the alternative reactions:

$$
\begin{aligned}
& 2 \mathrm{CH}_{4}+\mathrm{O}_{2} \rightarrow 2 \mathrm{CH}_{3} \mathrm{OH}, \\
& 2 \mathrm{CH}_{4}+\mathrm{O}_{2} \rightarrow \mathrm{CH}_{3} \mathrm{OCH}_{3}+\mathrm{H}_{2} \mathrm{O} .
\end{aligned}
$$

Reaction (5) was proposed by Wilkinson (I97I).

\section{Comparison of methane and carbon monoxide oxidation}

Effect of ammonium chloride. Ammonium ion inhibited methane oxidation by Methylosinus trichosporium Ов3в, and high $\mathrm{NH}_{4}^{+}$concentrations inhibited growth of some methaneutilizing bacteria to varied extents (Whittenbury, Phillips \& Wilkinson, 1970). Wilkinson (I97I) stated that $\mathrm{NH}_{4}^{+}$was a competitive inhibitor of methane oxidation. Double reciprocal plots (Lineweaver \& Burk, 1934) of the kinetics of methane-dependent $\mathrm{O}_{2}$ consumption show that $\mathrm{NH}_{4} \mathrm{Cl}$ competitively inhibited the oxidation of methane by $P$. methanica (Fig. 2a). Half-maximal rates of methane oxidation were reached at about $15 \mu \mathrm{M}$-methane concentration; this compares with an $\mathrm{S}_{0.5}$ for methane of $20 \mu \mathrm{M}$, found for a methane-oxidizing pseudomonad (Harrison, 1973). The $K_{i}$ for $\mathrm{NH}_{4} \mathrm{Cl}$ was about Io mM. As Whittenbury et al. (I970) stated that methane-utilizing bacteria could oxidize ammonia, it is relevant that, with 
$20 \mathrm{mM}-\mathrm{NH}_{4} \mathrm{Cl}$, the observed rate of $\mathrm{NH}_{4} \mathrm{Cl}$-dependent $\mathrm{O}_{2}$ consumption in these studies was below I nmol $\mathrm{O}_{2}$ consumed $/ \mathrm{min} / \mathrm{mg}$ dry wt cells. The effect of $\mathrm{NH}_{4} \mathrm{Cl}$ on the kinetics of $\mathrm{CO}$ oxidation by cell suspensions was followed by measuring rates of $\mathrm{CO}$-dependent $\mathrm{CO}_{2}$ formation in the presence of I mM-ethanol. The ethanol acted as the reductant for $\mathrm{CO}$ oxidation by intact cells, but its oxidation did not give rise to $\mathrm{CO}_{2}$ (Fig. $5 b$ ). Under these conditions (Fig. $2 b$ ) the $\mathrm{S}_{0.5}$ for $\mathrm{CO}$ was $2 \cdot 7 \mu \mathrm{M}$ and $\mathrm{NH}_{4} \mathrm{Cl}$ was a competitive inhibitor of $\mathrm{CO}$ oxidation, with a $K_{\mathrm{f}}$ of about $12 \mathrm{~mm}$. Ammonium chloride also inhibited NADHdependent $\mathrm{CO}$ oxidation by particulate membrane preparations : $23 \%$ at $20 \mathrm{~mm}$ and $35 \%$ at $40 \mathrm{~mm}$.

Effect of ethane. It was difficult to measure the competitive interaction of $\mathrm{CO}$ oxidation and methane oxidation because either oxidation resulted in the uptake of $\mathrm{O}_{2}$ and the formation of $\mathrm{CO}_{2}$. Ferenci (1974) showed that high concentrations of $\mathrm{CO}$ completely inhibited the oxidation of both substrates. Pseudomonas methanica oxidizes ethane to acetaldehyde and acetate, with only a small production of $\mathrm{CO}_{2}$ (Leadbetter \& Foster, I960). In the present short-term studies, the oxidation of ethane by $P$. methanica gave negligible rates of $\mathrm{CO}_{2}$ formation. Therefore the $\mathrm{CO}_{2}$ electrode was used to study the effect of $30 \mu \mathrm{M}-$ and $90 \mu \mathrm{M}-$ ethane on the kinetics of oxidation of $\mathrm{CO}$, using experimental conditions similar to those described in Fig. $2(b)$. Ethane competitively inhibited $\mathrm{CO}$ oxidation with a $K_{\mathrm{i}}$ of about $25 \mu \mathrm{M}$; the $\mathrm{S}_{0 \cdot 5}$ for $\mathrm{CO}$ in this experiment was $2 \cdot 3 \mu \mathrm{M}$.

Ethane also inhibited NADH-dependent $\mathrm{CO}$ oxidation by particulate membrane preparations: $42 \%$ at $90 \mu \mathrm{M}$ and $63 \%$ at $\mathrm{I} 80 \mu \mathrm{M}$. Both compounds (ethane and $\mathrm{NH}_{4} \mathrm{Cl}$ ) that inhibited CO oxidation by intact cells also inhibited the NADH-dependent oxidation of $\mathrm{CO}$, suggesting that the system responsible for the NADH-dependent activity is the same as that responsible for the oxidation of $\mathrm{CO}$ by intact cells. Cell-free extracts catalysed both ethanedependent NADH oxidation and, to a much lesser extent, an $\mathrm{NH}_{4} \mathrm{Cl}$-stimulated disappearance of NADH. Specific activities (nmol NADH oxidized $/ \mathrm{min} / \mathrm{mg}$ protein), using the spectrophotometric assay, were: methane, $27.8 ; \mathrm{CO}, 27 \cdot \mathrm{I} ; 0.3 \mathrm{~mm}$-ethane, I6.2; $100 \mathrm{~mm}$ $\mathrm{NH}_{4} \mathrm{Cl}, 7 \cdot 7$.

Stability on storage of extracts at $25^{\circ} \mathrm{C}$. Methane mono-oxygenase and $\mathrm{CO}$ monooxygenase activities were lost simultaneously, and separately from the substrate-independent NADH oxidase activity also present in extracts (Fig. 3).

$p H$-Dependence. The optimal $\mathrm{pH}$ for both the mono-oxygenase activities in phosphate buffer was $\mathrm{pH} 7 \cdot 0$, whereas optimal rates of substrate-independent NADH oxidase activity were reached at about $\mathrm{pH} 8$ (Fig. 4).

Enzyme inhibitors. The effect of enzyme inhibitors was measured spectrophotometrically using extracts. Dithiothreitol $(5 \mathrm{~mm})$ and reduced glutathione $(5 \mathrm{~mm})$ inhibited the methane mono-oxygenase by 84 and $63 \%$ respectively and the CO mono-oxygenase by 92 and $72 \%$ respectively; the substrate-independent NADH oxidase was not significantly affected by either compound. The inhibitions by sulphydryl reagents may not be due simply to a chelating effect, as Io mM-EDTA did not significantly inhibit any of the activities. Iodoacetic acid ( $2 \mathrm{mM}$ ) and $\mathrm{N}$-ethyl maleimide (I $\mathrm{mM}$ ) caused only minor inhibitions. Cyanide was a potent inhibitor of both mono-oxygenase activities and of the substrate-independent NADH oxidase, though the concentration of cyanide $(2 \mu \mathrm{M})$ that gave near-total inhibition of the mono-oxygenase activities only inhibited the activity of NADH oxidase by $50 \%$. The cyanide sensitivity of the NADH oxidase contrasts with the cyanide-insensitive NADH oxidase found by Davey, Whittenbury \& Wilkinson (1972) in extracts of various methaneutilizers. 


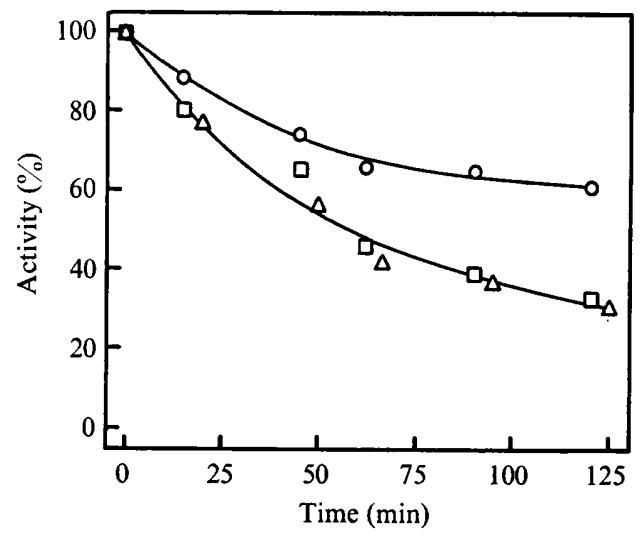

Fig. 3

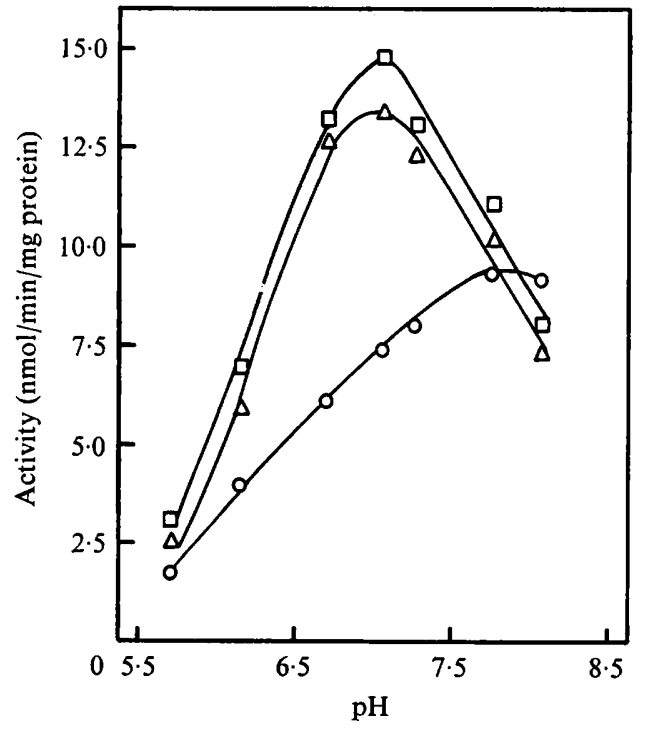

Fig. 4

Fig. 3. Stabilities of methane mono-oxygenase, $\mathrm{CO}$ mono-oxygenase and substrate-independent NADH oxidase activities at $25^{\circ} \mathrm{C}$. Samples from cell-free extract (Ferenci, I974) stored at $25^{\circ} \mathrm{C}$ and sampled at the times indicated, were assayed spectrophotometrically for NADH disappearance. The specific activities at the beginning of the experiment were (nmol NADH oxidized/min/mg protein): methane mono-oxygenase $(\square), 20 \cdot 6$; CO mono-oxygenase $(\triangle), 19 \cdot 4$; substrate-independent NADH oxidase (O), 10.2.

Fig. 4. pH-dependence of methane mono-oxygenase, $\mathrm{CO}$ mono-oxygenase and substrate-independent NADH oxidase activities. Methane mono-oxygenase ( $\square$ ), CO mono-oxygenase $(\triangle)$ and substrate-independent NADH oxidase $(O)$ activities were assayed spectrophotometrically in $50 \mathrm{~mm}-$ sodium phosphate buffer at the $\mathrm{pH}$ values indicated.

\section{Generation of reductant for the mono-oxygenase in intact organisms}

The mechanism whereby ethanol could act as the source of reductant for the mono-oxygenase was investigated (Fig. 5). The oxidation of $\mathrm{CO}$ to $\mathrm{CO}_{2}$ and the concomitant faster $\mathrm{O}_{2}$ uptake were dependent on ethanol; the rate of $\mathrm{CO}_{2}$ formation from $\mathrm{CO}$ (Fig. 5a) was slow and that from ethanol (Fig. $5 b$ ) negligible, when these substrates were present separately. When small amounts of $\mathrm{CO}$ were added to organisms oxidizing ethanol (Fig. $5 b$ ) the stimulated rates of $\mathrm{O}_{2}$ consumption and $\mathrm{CO}_{2}$ formation only continued until the added $\mathrm{CO}$ had been exhausted. During CO-stimulated respiration, virtually the complete rate of $\mathrm{O}_{2}$ consumption could be accounted for by the rate of $\mathrm{CO}$ oxidation to $\mathrm{CO}_{2}$; the mono-oxygenase may therefore have been acting as the terminal oxidase for the reducing power generated from ethanol oxidation. The nearly twofold stimulation of the rate of $\mathrm{O}_{2}$ consumption by the organism oxidizing ethanol after addition of $\mathrm{CO}$ was consistent with a switch from a normal terminal oxidase catalysing:

$$
4 \mathrm{H}+\mathrm{O}_{2} \rightarrow 2 \mathrm{H}_{2} \mathrm{O}
$$

to the mono-oxygenase catalysing:

$$
2 \mathrm{H}+\mathrm{O}_{2}+\mathrm{CO} \rightarrow \mathrm{H}_{2} \mathrm{O}+\mathrm{CO}_{2} .
$$

No NAD-linked enzyme was found to be involved in the oxidation of ethanol by $P$. methanica, which is limited to partial oxidation to acetate (Leadbetter \& Foster, 1958) and 


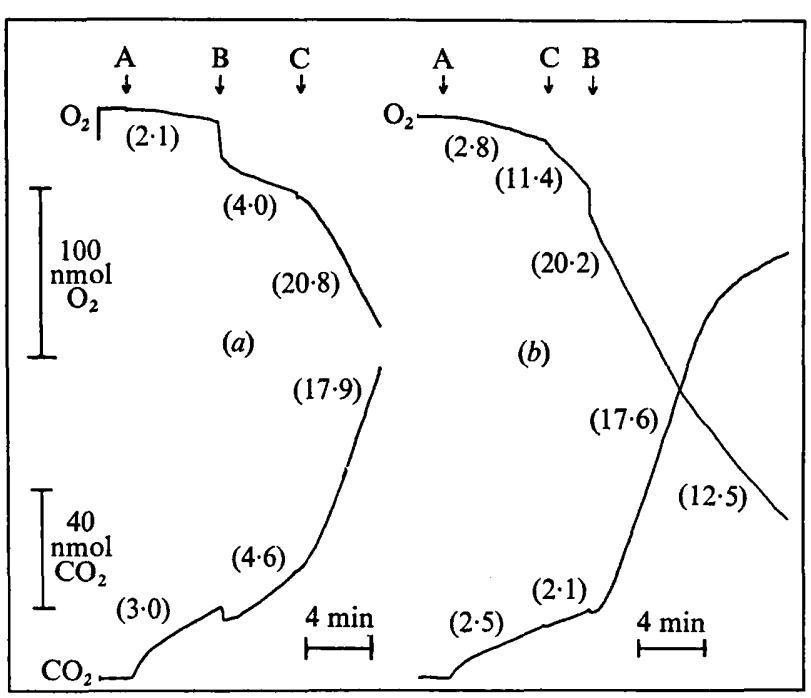

Fig. 5

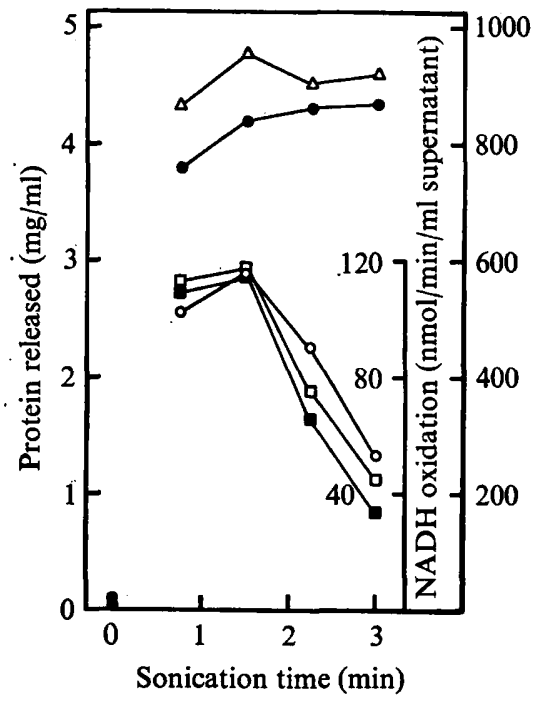

Fig. 6

Fig. 5. Ethanol-dependent $\mathrm{CO}$ oxidation by cell suspensions. The reaction mixtures (total volume $2 \mathrm{ml}$ in the dual $\mathrm{CO}_{2}-\mathrm{O}_{2}$ electrode vessel) initially contained $50 \mathrm{~mm}$-sodium-potassium phosphate buffer $\mathrm{pH} 7.0$ and $200 \mu \mathrm{g}$ carbonic anhydrase. The following were added at the times indicated: $\mathrm{A}$, $0.26 \mathrm{mg}$ dry wt $P$. methanica; B, $93 \mathrm{nmol} \mathrm{CO;} \mathrm{C,} 2 \mu \mathrm{mol}$ ethanol. Two experiments, $(a)$ and $(b)$; were performed, with the additions made in a different order. The figures in parentheses give the rates of $\mathrm{O}_{2}$ consumption or $\mathrm{CO}_{2}$ formation, in $\mathrm{nmol} / \mathrm{min}$.

Fig. 6. Effect of length of sonic disruption on $P$. methanica. Suspensions $(6 \mathrm{ml})$ cooled in ice, were treated with an MSE $150 \mathrm{~W}$ ultrasonic disintegrator using the 3/8 inch-diamater titanium probe. The disintegrator was used at the 'low' power setting, with a transducer amplitude of about $7.5 \mu \mathrm{m}$ peak to peak. Treatment was for $45 \mathrm{~s}$ periods, between which both the suspensions and the probe were cooled in ice-water for $1 \mathrm{~min}$. The resultant preparations were centrifuged at $6000 \mathrm{~g}$ for $10 \mathrm{~min}$. The supernatants were assayed for: $\bullet$, protein released; $\triangle$, formate dehydrogenase activity; $\square$, methane mono-oxygenase activity; $\mathbf{n}, \mathrm{CO}$ mono-oxygenase activity; $O, \mathrm{NADH}$ oxidase activity. The spectrophotometric assay of NADH oxidation was used for $\square, \square$ and $O$.

not to $\mathrm{CO}_{2}$ (Fig. 5 b). Acetaldehyde can be oxidized by $P$. methanica, but acetate cannot. A dehydrogenase activity dependent on ammonium ions and coupled to PMS could be demonstrated (Table 2); methanol, ethanol, formaldehyde and acetaldehyde were all substrates in the PMS-linked assay. It is likely all these activities are due, at least in part, to the presence of the same enzyme, namely the primary alcohol dehydrogenase of broad substrate specificity purified from $M$. capsulatus (Patel et al. 1972) and methanol-utilizing bacteria (Sperl, Forrest \& Gibson, 1974). An alcohol (and aldehyde) oxidase activity independent of added electron acceptor was also observed (Table 2). A similar oxidase activity has been found in $M$. capsulatus by Wadzinski \& Ribbons (1975). The glutathione-dependent NADlinked formaldehyde dehydrogenase activity described by Johnson \& Quayle (1964) was not detected in extracts of $P$. methanica, even when bacteria were grown and extracts prepared under identical conditions; nor was an NAD-linked acetaldehyde dehydrogenase activity observed.

From these results, it appeared that no substrate-level reduction of NAD was involved in the metabolism of ethanol by P. methanica. Ethanol was tested directly as a reductant with extracts. No ethanol-dependent $\mathrm{CO}_{2}$ formation from $\mathrm{CO}$ could be detected with particulate membrane preparations. even though these preparations were capable of NADH-dependent 
Table 2. The alcohol and aldehyde oxidase and dehydrogenase activities in cell-free extracts and the effect of sonication

The procedure for the assays and the concentrations of substrates used are described in Methods. The endogenous rate of $\mathrm{O}_{2}$ uptake, $0.8 \mathrm{nmol} \mathrm{O} / \mathrm{min} / \mathrm{mg}$ protein, was subtracted to obtain the values shown below. Activities are expressed in units of $\mathrm{nmol} \mathrm{O}_{2}$ consumed $/ \mathrm{min} / \mathrm{mg}$ protein.

\begin{tabular}{|c|c|c|c|c|c|c|}
\hline & \multicolumn{6}{|c|}{ Time of sonication } \\
\hline & \multicolumn{3}{|c|}{$\mathrm{I} \cdot 5 \mathrm{~min}$} & \multicolumn{3}{|c|}{$3.0 \mathrm{~min}$} \\
\hline & $\begin{array}{l}\text { Without } \\
\text { additions }\end{array}$ & $+\mathrm{NH}_{4} \mathrm{Cl}$ & $\begin{array}{c}+\mathrm{NH}_{4} \mathrm{Cl} \\
+\mathrm{PMS}\end{array}$ & $\begin{array}{l}\text { Without } \\
\text { additions }\end{array}$ & $+\mathrm{NH}_{4} \mathrm{Cl}$ & $\begin{array}{c}+\mathrm{NH}_{4} \mathrm{Cl} \\
+\mathrm{PMS}\end{array}$ \\
\hline Methanol & $14 \cdot 3$ & $19 \cdot 9$ & $52 \cdot 8$ & $4 \cdot 8$ & $4 \cdot 8$ & $37 \cdot 1$ \\
\hline Ethanol & $14 \cdot 6$ & $17 \cdot 9$ & $57 \cdot 5$ & $4 \cdot 8$ & $5 \cdot 0$ & $39 \cdot 0$ \\
\hline Formaldehyde & $13 \cdot 7$ & $16 \cdot 5$ & $5 \mathrm{I} \cdot \mathrm{I}$ & $4 \cdot 5$ & $4 \cdot 5$ & $37 \cdot 9$ \\
\hline Acetyldehyde & 10.9 & $14 \cdot 0$ & $39 \cdot 2$ & $4 \cdot 5$ & $4 \cdot 5$ & $36 \cdot 0$ \\
\hline
\end{tabular}

$\mathrm{CO}$ oxidation and also possessed alcohol oxidase activity. Methane-dependent respiration by intact organisms was not stimulated by ethanol; this was not unexpected, as the complete oxidation of methane to $\mathrm{CO}_{2}$ should give rise to more than enough reductant to ensure the initial oxygenation of methane. In contrast, the oxidation of ethane (which was originally at a rate of $16.3 \mathrm{nmol} \mathrm{O}_{2}$ consumed $/ \mathrm{min} / \mathrm{mg}$ dry wt cells, i.e. one-fifth the rate of methane) was stimulated by exogenously supplied ethanol or formate to $3 \mathrm{I} \cdot 5$ or $55^{\circ} 0$, respectively. A similar stimulation by formate and ethanol of the rates of $\mathrm{CO}$ oxidation has been observed previously (Ferenci, 1974).

\section{Release by ultrasonic disruption of the enzymes involved in the oxidation of one-carbon compounds}

Not all the factors governing the initial specific activity and stability of the methane mono-oxygenase system in cell-free extracts are understood. Although the procedure of Ferenci (1974) for the growth of cells and preparation of extracts was adhered to, the specific activities of the extracts used in these studies varied between 15 and $30 \mathrm{nmol}$ NADH oxidized $/ \mathrm{min} / \mathrm{mg}$ protein for both $\mathrm{CO}$ mono-oxygenase and methane mono-oxygenase activities, in 85 to $90 \%$ of extracts prepared.

The treatment time used in breaking the organisms by ultrasonication strongly affected the final enzyme activities (Fig. 6). As $P$. methanica is relatively fragile, $45 \mathrm{~s}$ treatment under the conditions outlined in the legend to Fig. 6 released over $80 \%$ of the protein, together with the other activities illustrated, into a supernatant obtained by centrifuging at $6000 \mathrm{~g}$ for $10 \mathrm{~min}$. Treatment for a further $45 \mathrm{~s}$ resulted in a slight increase in all the activities tested, but longer periods resulted in a sharp decrease of all activities except the formate dehydrogenase.

As the membrane-bound enzymes (the methane/CO mono-oxygenase, NADH oxidase, alcohol oxidase; Table 2) lost more activity than the soluble enzymes (formate dehydrogenase, primary alcohol dehydrogenase), the destructive effect of ultrasonic treatment may have been due to the disruption of the complex membrane structure characteristic of methaneutilizing bacteria (Davies \& Whittenbury, 1970). 


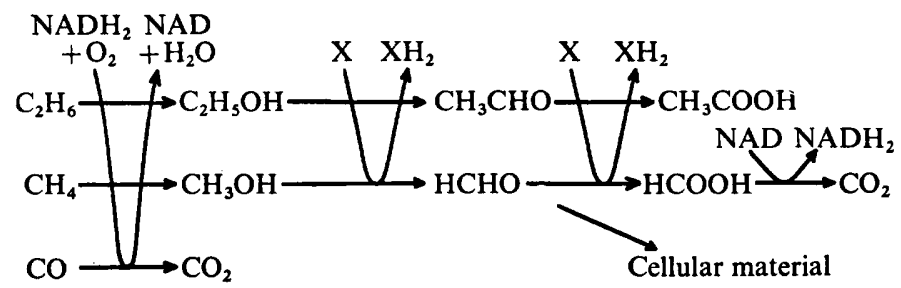

Fig. 7. Scheme for the oxidative metabolism of $P$. methanica. $\mathrm{X}$ represents the unknown physiological electron acceptor for the reations catalysed by the primary alcohol dehydrogenase.

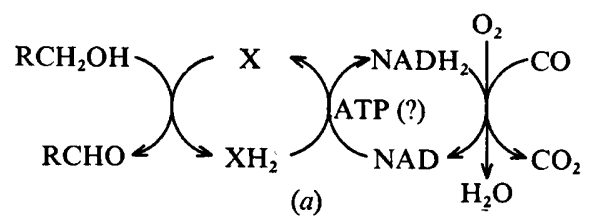

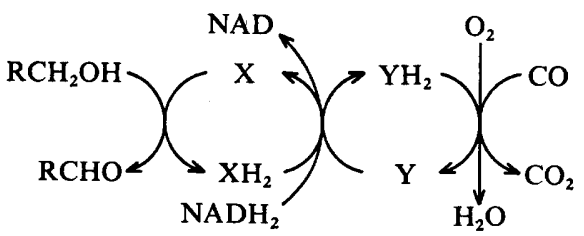

(b)

Fig. 8. Scheme for two possible routes, $(a)$ and $(b)$, for the channelling of reductant from alcohol oxidation to the $\mathrm{CO}$ mono-oxygenase. $\mathrm{X}$ represents the unknown physiological electron acceptor for the reactions catalysed by the primary alcohol dehydrogenase, and $Y$ represents a postulated carrier or set of electron carriers between NADH and the CO mono-oxygenase.

\section{DISCUSSION}

The evidence presented in this paper and elsewhere (Ribbons et al. 1970; Ribbons \& Michalover, 1970; Quayle, 1972) is consistent with the pattern of oxidative metabolism shown in Fig. 7. Proof that the $\mathrm{CO}$ and ethane mono-oxygenase activities are secondary activities of the methane mono-oxygenase will have to await purification of the enzyme(s) responsible for these activities, but the evidence so far strongly suggests that these activities are catalysed by the same enzyme system. Indeed, in no property tested in cell-free extracts have the three activities differed significantly; the only major difference between $\mathrm{CO}$, ethane and methane oxidation by whole cells is that a co-oxidizable substrate is required for $\mathrm{CO}$ oxidation and stimulates ethane oxidation. This is entirely consistent with the involvement of a mono-oxygenase in these oxidations. By several criteria, the mono-oxygenase activities in extracts' behaved differently from the substrate-independent NADH oxidase activity. Therefore it is likely that NADH oxidase involves at least one protein distinct from those required for mono-oxygenase activity, which makes it unlikely that the observed methane-, ethaneand CO-dependent stimulations of NADH oxidation resulted from stimulation of the substrate-independent NADH oxidase.

The physiological significance, if any, of the ability of $P$. methanica to oxidize CO and ethane is probably limited to that of co-metabolism. Pseudomonas methanica is unable to 
grow on $\mathrm{CO}$ or ethane as a source of carbon and energy, and $\mathrm{CO}$ inhibits the growth of $P$. methanica on either methane or methanol (Ferenci, 1974). Ethane is also inhibitory to the growth on methane of some methane-utilizing bacteria (Whittenbury et al. 1970).

The interaction of the mono-oxygenase with $\mathrm{CO}$ offers advantages over methane in studies of the methane mono-oxygenase system. The oxidation of $\mathrm{CO}$ is a one-step oxidation with $\mathrm{CO}_{2}$ as product, which can be sensitively and continuously assayed by the procedure described in this paper. The oxidation of methane by the relatively crude membrane systems now available results in the formation of a number of products as methanol is further metabolized, in some circumstances as far as $\mathrm{CO}_{2}$ (unpublished observations). If, as the whole-cell oxidation studies indicate, the reductant for the mono-oxygenase can be generated from further oxidation of methanol, there are advantages in using for the mono-oxygenase a substrate such as $\mathrm{CO}$ which cannot generate any reductant through further oxidation.

The involvement of a mono-oxygenase in methane oxidation demands that $\mathrm{I}$ mol of reducing agent be utilized for each mole of methane utilized. During growth of $P$. methanica on methane, most of the carbon is channelled to cellular material at the level of formaldehyde (Kemp \& Quayle, ${ }^{1967}$ ) and a smaller proportion of methane is oxidized to $\mathrm{CO}_{2}$, as can be judged from the growth stoicheiometry data collected by Quayle (1972). Therefore during growth on methane, the relatively low amounts of NADH produced from further oxidation of formaldehyde (Fig. 7) might be insufficient to allow an NADH-linked monooxygenase to catalyse methane oxidation. It has been postulated that NADH might be generated from the reductant formed from alcohol and aldehyde oxidation (designated $\mathrm{XH}_{2}$ in Fig. 7), by energy-dependent reversed electron transport as in Fig. 8(a) (Van Dijken \& Harder, I975). However, as the half-reduction potential of the $\mathrm{X}-\mathrm{XH}_{2}$ couple is unknown, it is premature to postulate energy-dependence for the reduction of NAD by $\mathrm{XH}_{2}$. Nor need reversal of electron transport to generate $\mathrm{NADH}$ be invoked if $\mathrm{XH}_{2}$ itself is the reducing agent for the mono-oxygenase or can reduce the true agent $\mathrm{Y}$ as in Fig. 8(b). Such intermediate electron carriers have been recognized between NADH and several other monooxygenases (Peterson et al. 1967; Gunsalus et al. 1974; Kaufman \& Fisher, 1974). The present results indicate that alcohol oxidation can supply reducing power to the monooxygenase in vivo; its failure to do so in cell-free extracts could be due to the absence of conditions for reversed electron transport to take place, or to disruption, solubilization or dilution of essential electron transfer components on preparation of extracts.

Ribbons et al. (1970), Kelly (I97I) and Wilkinson (197I) have pointed out the similarities between methane-utilizing bacteria and lithotrophic bacteria. There is a striking similarity between the methane-CO mono-oxygenase system in $P$. methanica and the ammonia-oxidizing system recently described by Suzuki (1974) in Nitrosomonas. The analogy between hydroxylamine (or $\mathrm{NADH}$ ) stimulating ammonia oxidation by cell-free extracts or hydroxylamine stimulating ammonia oxidation by whole cells or sphaeroplasts (Hooper, 1969; Suzuki \& Kwok, I969), and the effect of alcohols on the methane-CO mono-oxygenase system in whole cells of $P$. methanica, is clear. Ammonia oxidation is strongly inhibited by $\mathrm{CO}$ (Hooper \& Terry, 1973) though whether $\mathrm{CO}$ is oxidized by Nitrosomonas was not tested. Carbon monoxide can be oxidized by a variety of bacteria other than methane-utilizers, as reviewed by Schlegel (1974), though by mechanisms different from that found in $P$. methanica.

The non-reproducibility and instability of methane-oxidizing activity in extracts of methane oxidizing bacteria have hitherto hindered study of the oxidative enzymes involved. The reproducibility of the mono-oxygenase activity in extracts of $P$. methanica, the recognition of its sensitivity to sonication, and awareness of the advantages of using $\mathrm{CO}$ as a substrate analogue of methane may aid future studies in this field. 
We thank the Science Research Council for financial support under grant No. B/RG/ 27 I I8, and Norges Teknisk-Naturvitenskapelige Forskningsråd for additional support to T.S.

\section{REFERENCES}

Davey, J. F., Whittenbury, R. \& Wilkinson, J. F. (1972). The distribution in the Methylobacteria of some key enzymes concerned with intermediary metabolism. Archiv für Mikrobiologie 87, 359-366.

Davies, S. L. \& Whittenbury, R. (1970). Fine structure of methane and other hydrocarbon-utilizing bacteria. Journal of General Microbiology 6r, 227-232.

FERENCI, T. (1974). Carbon monoxide-stimulated respiration in methane-utilizing bacteria. FEBS Letters 4I, $94-98$.

Foster, J. W. (1962). Bacterial oxidation of hydrocarbons. In The Oxygenases, pp. 24I-27I. Edited by $O$. Hayaishi. New York: Academic Press.

Gunsalus, I. C., Meeks, J. R., Lipscomb, J. D., Debrunner, P. \& Münk, E. (1974). Bacterial monooxygenases - the $\mathrm{P} 450$ cytochrome system. In Molecular Mechanisms of Oxygen Activation, pp. 559-613. Edited by $\mathrm{O}$. Hayaishi. New York and London: Academic Press.

HARRISON, D. E. F. (1973). Studies on the affinity of methanol- and methane-utilizing bacteria for their carbon substrates. Journal of Applied Bacteriology 36, 301-308.

Hooper, A. B. (1969). Lag phase of ammonia oxidation by resting cells of Nitrosomonas europaea. Journal of Bacteriology 97, 968-969.

HoOPER, A. B. \& TERRY, K. R. (1973). Specific inhibitors of ammonia oxidation in Nitrosomonas. Journal of Bacteriology II5, 480-485.

Hubley, J. H., Mitton, J. R. \& Wilkinson, J. F. (I974). The oxidation of carbon monoxide by methaneoxidizing bacteria. Archives of Microbiology 96, 365-368.

Johnson, P. A. \& QuAYle, J. R. (I964). Microbial growth on $\mathbf{C}_{1}$ compounds - oxidation of methanol, formaldehyde and formate by methanol-grown Pseudomonas AMI. Biochemical Journal 93, 28I-290.

Kaufman, S. \& Fisher, D. B. (1974). Pterin-requiring aromatic amino acid hydroxylases. In Molecular Mechanisms of Oxygen Activation, pp. 285-369. Edited by O. Hayaishi. New York and London: Academic Press.

Kelly, D. P. (197I). Autotrophy: concepts of lithotrophic bacteria and their organic metabolism. Annual Review of Microbiology 25, $177-210$.

KemP, M. B. \& QuAYLE, J. R. (I967). Microbial growth on $\mathrm{C}_{1}$ compounds. Uptake of [ $\left.{ }^{14} \mathrm{C}\right]$ formaldehyde and $\left[{ }^{14} \mathrm{C}\right]$ formate by methane-grown Pseudomonas methanica and determination of the hexose labelling pattern after brief incubation with $\left[{ }^{14} \mathrm{C}\right]$ methanol. Biochemical Journal 102, 94-102.

Leadbetter, E. R. \& Foster, J. W. (1958). Studies on some methane-utilizing bacteria. Archiv für Mikrobiologie 30, $9 \mathrm{I}-1 \mathrm{I} 8$.

LeAdbetTER, E. R. \& Foster, J. W. (1960). Bacterial oxidation of gaseous alkanes. Archiv für Mikrobiologie 35, 92-104.

LineweAver, H. \& BURK, D. (1934). The determination of enzyme dissociation constants. Journal of the American Chemical Society 56, 658-666.

Lowry, O. H., Rosebrough, N. J., Farr, A. L. \& Randall, R. J. (195I). Protein measurement with the Folin phenol reagent. Journal of Biological Chemistry 193, 265-275.

Nicholls, D. G., Shepherd, D. \& Garland, P. B. (I967). A continuous recording technique for the measurement of carbon dioxide and its application to mitochondrial oxidation and decarboxylation reactions. Biochemical Journal 103, 677-69I.

Patel, R. N., Bose, H. R., Mandy, W. J. \& Hoare, D. S. (1972). Physiological studies of methane- and methanol-oxidizing bacteria: comparison of a primary alcohol dehydrogenase from Methylococcus capsulatus (Texas strain) and Pseudomonas species M27. Journal of Bacteriology 110, 570-577.

Peterson, J. A., Kusunose, M., Kusunose, E. \& Coon, M. J. (1967). Function of rubredoxin as the electron carrier in $\omega$-hydroxylation. Journal of Biological Chemistry 242, 4334-4340.

QUAYLE, J. R. (1972). The metabolism of one-carbon compounds by micro-organisms. Advances in Microbial Physiology 7, I19-203.

Ribbons, D. W., Harrison, J. E. \& Wadzinski, A. M. 1970). Metabolism of single carbon compounds. Annual Review of Microbiology 24, I35-I 58.

Ribbons, D. W. \& Michalover, J. L. (1970). Methane oxidation by cell-free extracts of Methylococcus capsulatus. FEBS Letters II, 4I-44. 
Schlegel, H. G. (1974). Production, modification and consumption of atmospheric trace gases by microorganisms. Tellus $26,1 \mathrm{I}-20$.

Seidell, A. (1920). Solubilities of Inorganic and Organic Substrates, 2nd edn. London: Crosby, Lockwood and Son.

SPerL, G. T., Forrest, H. S. \& Gibson, D. T. (I974). Substrate specificity of the purified primary alcohol dehydrogenase from methanol-oxidizing bacteria. Journal of Bacteriology 118, 54I-550.

SuzUKI, I. (1974). Mechanisms of inorganic oxidation and energy coupling. Annual Review of Microbiology 28, 85-101.

SuzukI, I. \& Kwok, S. C. (1969). Oxidation of ammonia by spheroplasts of Nitrosomonas europaea. Journal of Bacteriology 99, 897-898.

VAN DiJKen, J. P. \& HaRder, W. (I975). Growth yields of micro-organisms on methanol and methane. A theoretical study. Biotechnology and Bioengineering 27, $15-30$.

WADZINSKI, A. M. \& RibBons, O. W. (1975). Oxidation of $\mathbf{C}_{1}$ compounds by particulate fractions from Methylococcus capsulatus: properties of methanol oxidase and methanol dehydrogenase. Journal of Bacteriology 122, 1364-1 374.

Whittenbury, R. (1969). Microbial utilization of methane. Process Biochemistry 1, 5I-56.

Whittenbury, R., Phillips, K. C. \& Wilkinson, J. F. (1970). Enrichment, isolation and some properties of methane-utilizing bacteria. Journal of General Microbiology 6r, 205-218.

Wilkinson, J. F. (197I). In Microbes and Biological Productivity, pp. 15-46. Edited by D. E. Hughes and A. H. Rose. Cambridge: Cambridge University Press. 